\title{
MATHEMATICAL MODELING OF A CEMENT RAW-MATERIAL BLENDING PROCESS USING A NEURAL NETWORK
}

\author{
MATEMATIČNO MODELIRANJE POSTOPKA MEŠANJA SESTAVIN \\ CEMENTA S POMOČJO NEVRONSKE MREŽE
}

\author{
Aysun Egrisogut Tiryaki, Recep Kozan, Nurettin Gokhan Adar \\ Sakarya University, Department of Mechanical Engineering, 54187, Sakarya, Turkey \\ aysune@sakarya.edu.tr \\ Prejem rokopisa - received: 2014-08-01; sprejem za objavo - accepted for publication: 2015-06-30 \\ doi:10.17222/mit.2014.156
}

\begin{abstract}
Raw-material blending is an important process affecting cement quality. The aim of this process is to mix a variety of materials such as limestone, shale, sandstone and iron to produce cement raw meal for the kiln. One of the fundamental problems in cement manufacture is ensuring the appropriate chemical composition of the cement raw meal. A raw meal with a good fineness and well-controlled chemical composition by a control system can improve the cement quality. The first step in designing a control system for the process is obtaining an appropriate mathematical model. In this study, Linear and Nonlinear Neural Network models were investigated for the raw-material blending process in the cement industry and their results were compared with the experimental data. The results showed that the nonlinear model has a higher predictive accuracy.

Keywords: mathematical modeling, cement, raw material blending, neural network
\end{abstract}

Mešanje sestavin je pomemben postopek, ki vpliva na kvaliteto cementa. Naloga tega postopka je zmešati različne materiale, kot so: apnenec, škrilavec, peščenjak, železo in drugi; da se dobi surovino za cement za rotacijsko peč. Ena od osnovnih težav pri izdelavi cementa je zagotoviti primerno kemijsko sestavo surovine za cement. Kontrolni sistem za surovino $\mathrm{z}$ dobro zrnatostjo in dobro kontrolirano kemijsko sestavo, lahko izboljša kvaliteto cementa. Prvi korak pri postavitvi kontrole procesa je postavitev primernega matematičnega modela procesa. V študiji sta bila preiskovana linearni in nelinearni model nevronske mreže za postopek mešanja $v$ cementni industriji in rezultati so bili primerjani z eksperimentalnimi podatki. Rezultati so pokazali, da ima nelinearni model večjo točnost napovedovanja.

Ključne besede: matematično modeliranje, cement, mešanje surovin, nevronska mreža

\section{INTRODUCTION}

Cement is the world's most widely used construction material and is a key ingredient in concrete. The cement manufacturing process includes the raw-materials blending process as well as the burning process, the cement clinker grinding process, and the packaging process. One of the main processes that effects cement quality is the raw-material blending process. The task of this process is to mix a variety of materials such as limestone, shale, sandstone, and iron, to produce cement raw meal for the kiln. Raw meal mainly contains four oxides: calcium oxide or lime $(\mathrm{CaO})$, silica $\left(\mathrm{SiO}_{2}\right)$, alumina $\left(\mathrm{Al}_{2} \mathrm{O}_{3}\right)$ and iron oxide $\left(\mathrm{Fe}_{2} \mathrm{O}_{3}\right)$. The oxide compositions of the raw meal significantly affect the quality and the properties of cement clinker. On the other hand, the chemical compositions of the raw materials vary from time to time and the feeder tanks do not contain chemically homogeneous raw materials. That is why blend estimating systems with computer control are needed to obtain the correct composition of the blend.

The approaches to the solution of this fundamental blending problem have varied widely. Stochastic modeling, which uses experimental process data and the characteristics of the various disturbances, and selftuning control of a continuous cement raw-material mixing system were presented in ${ }^{1}$. A recursive estimation of the cement raw-material feedstream oxide concentrations was presented by using information from the output raw meal X-ray analysis. ${ }^{2} \mathrm{~L}$. Keviczky et al. ${ }^{3}$ modified the self-tuning (ST) minimum variance (MV) regulator algorithm developed for a multiple input multiple output (MIMO) system presented with the required average for finite time (RAFT). P. Lin et al. ${ }^{4}$ proposed a two-level adaptive control policy combined with a heuristic auxiliary system for the robustness of the raw mix control system. A new generic optimal controller structure, which is equivalent to those used at internal model principal or pole placement technique, was dealt with in ${ }^{5}$. C. Ozsoy et al. ${ }^{6}$ presented a constrained self-tuning composition control algorithm for a MIMO system. The identification and control of the cement raw-material blending system in a cement factory were examined and in the identification part of the studies, three different linear multivariable stochastic time-series models (ARX) in which the inputs are the feed ratios of the raw-material components (low grade and iron ore) and the outputs are the iron oxide and/or the lime module of the raw meal, were constructed. ${ }^{7} \mathrm{~K}$. Kizilaslan et al. ${ }^{8}$ modeled the rawmaterial blending process in the cement industry using intelligent techniques and the results are compared with 
classic system-identification methods. A fuzzy controller is proposed to improve the real-time performance in the blending process. ${ }^{9}$ An adaptive control framework was presented for the raw-material blending process, and the corresponding optimal control structure was discussed too. ${ }^{10}$ A fuzzy neural network with particle-swarm optimization FNN-PSO methods was applied to establish and optimize the cement raw-material blending process in ${ }^{11}$. The ingredient ratio optimization problem was analyzed using the general nonlinear time-varying (G-NLTV) model for the cement raw-material blending process under various conditions by $\mathrm{X}$. Li et al. ${ }^{12}$

The first step in applying an adaptive and dynamic control strategy to this kind of process is obtaining an appropriate mathematical model of the process. This paper is concerned with modeling the raw-material blending process in cement industry by using neural networks. Linear and Nonlinear Neural Network models were developed and the results were compared with the experimental data.

\section{CEMENT RAW-MATERIAL BLENDING PROCESS}

The cement -manufacturing process consists broadly of mining, crushing and grinding, burning, and grinding with gypsum. In the dry process of cement production, the raw materials are proportioned, stored, ground, mixed, pulverized, and fed into the kiln in a dry state. Inside the kiln the raw mix will undergo a sequence of reactions. Sintering takes place at the final stage of the reaction, i.e., at $1400-1450{ }^{\circ} \mathrm{C}$, and a substance called clinker, having its own physical and chemical properties, is formed. The clinker is cooled, crushed, and mixed with a predetermined percentage of gypsum to regulate the setting time of the cement. Finally, the finished pro-

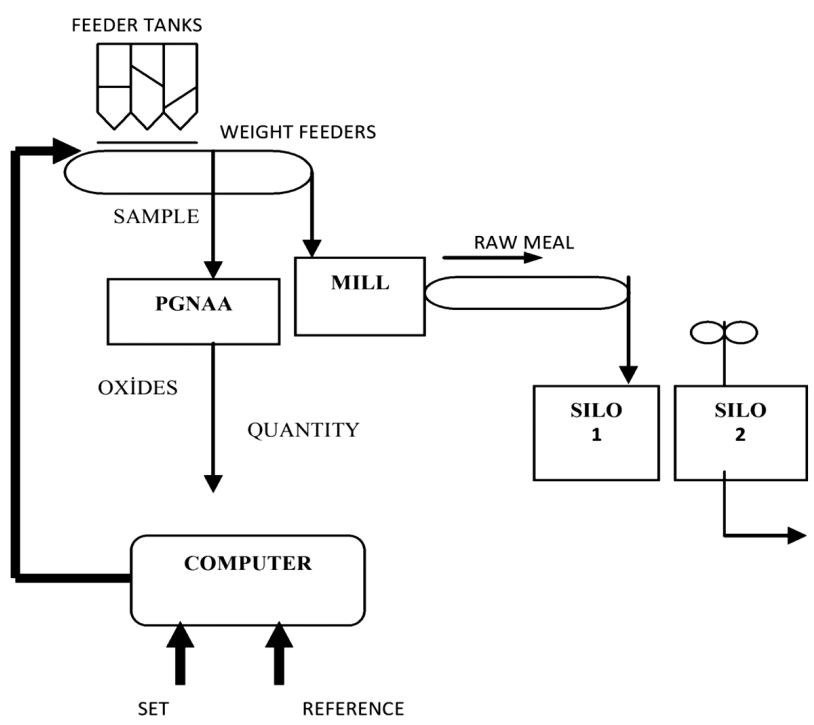

Figure 1: Simple schema of the raw-material blending in the Nuh Cement Factory

Slika 1: Preprosta shema mešanja surovin v tovarni cementa Nuh duct, known as Portland cement, is stored in large storage bins called silos, from which it is fed to an automatic packing machine. ${ }^{8}$

The original cement materials are obtained from a natural mine, thus the chemical composition is timevarying function. Composition fluctuation is inevitable and it may contain randomness. Therefore, modeling of the cement raw-material blending process becomes more important and a challenge.

In this study, the raw material blending process in the Nuh Cement Factory in Turkey was investigated. Here, three different feed streams, which are low grade, high grade and iron ore, are controlled by weigh feeders and, after mixing on a conveyor belt, fed to the raw mill. A simplified schematic diagram of the raw mill blending process is shown in Figure 1.

Mixing on a conveyor belt is fed to the raw mill by weight-feeders, before being thoroughly ground and mixed in the raw mill. In this study, two feed streams containing low grade and iron ore were modeled, because the values of all the measurements are a percentage. A sample of this raw mix is collected at the input of the raw mill grinder by an auto sampler and analyzed every five seconds and the average of twelve analyses is sent to the computer through a data-communication line by PGNAA (Prompt Gamma Neutron Activation Analyzers). These data are utilized and manipulated for the raw meal feed stream. Thus, the desired blend is supplied continuously. The measurements consist of the output concentrations of the four basic oxides $\left(\mathrm{CaO}, \mathrm{SiO}_{2}, \mathrm{Fe}_{2} \mathrm{O}_{3}\right.$ and $\left.\mathrm{Al}_{2} \mathrm{O}_{3}\right)$. The raw meal is transferred to homogenization basins where further continuous mixing decreases the magnitude of the concentration variations about the silo average values. The complete filling of a basin requires a unit batch time of $16 \mathrm{~h}$.

The quality of raw meal depends on the relative rates of $\mathrm{CaO}, \mathrm{SiO}_{2}, \mathrm{Fe}_{2} \mathrm{O}_{3}$ and $\mathrm{Al}_{2} \mathrm{O}_{3}$. The relative rates can be expressed by the so-called modulus values: ${ }^{8,12}$

Lime standard (or modulus):

$$
M L=\frac{100 \mathrm{CaO}}{2.8 \mathrm{SiO}_{2}+1.1 \mathrm{Al}_{2} \mathrm{O}_{3}+0.8 \mathrm{Fe}_{2} \mathrm{O}_{3}}
$$

Aluminum modulus:

$$
M A=\frac{\mathrm{Al}_{2} \mathrm{O}_{3}}{\mathrm{Fe}_{2} \mathrm{O}_{3}}
$$

Silica modulus:

$$
M S=\frac{\mathrm{SiO}_{2}}{\mathrm{Al}_{2} \mathrm{O}_{3}+\mathrm{Fe}_{2} \mathrm{O}_{3}}
$$

A high $M L$ requires a high heat consumption for the clinker burning inside the kiln and thus gives more strength to the cement. A higher $M S$ decreases the liquid-phase content, which impairs the burn ability of the clinker and reduces the cement setting time. The 
value of $M A$ determines the composition of the liquid phase of the clinker. The goal is to achieve a desired level of $M L, M S$ and $M A$ of the raw mix, to produce a particular quality of the cement by controlling the mix proportions of the raw materials. To achieve an appropriate raw mix proportion is very difficult due to the inconsistencies in the chemical composition of the raw material. ${ }^{8}$

\section{ARTIFICIAL NEURAL NETWORK APPROACH}

The Artificial Neural Network (ANN) has been developed by a generalization of the mathematical model of the human brain's ability and neural biology. The ANN, which is relatively new modeling technique, has shown remarkable performance when used to model complex linear and non-linear relationships. Neural Networks (NN) have been successfully applied to model complicated processes in many engineering applications: electronics, manufacturing, robotics, materials science and physical metallurgy, automotive, defense, and telecommunications. An ANN is a set of processing elements, or neurons, and connections with adjustable weights. A multi-layer neural network consists of an input layer, one or more hidden layers, and an output layer. The input layer is the first layer and accepts symptoms, signs, and experimental data. The layers that are placed between the input and output layers are called hidden layers. The hidden layer processes the data it receives from the input layer, and sends a response to the output layer. The output layer accepts all the responses from the hidden layer and produces an output vector. Figure 2 shows the structure of the ANN.

Each layer has a certain number of processing elements that are connected by links with adjustable weights. These weights are adapted during the training process, most commonly through the backpropagation algorithm, by presenting the neural network with examples of input-output pairs exhibiting the relationship the network is attempting to learn.

The total input to the layer neuron $i, x i$, is the summation of the weight $\left(w_{i j}\right)$, which is associated with the connection between the neuron $i$ and the neuron $j$,

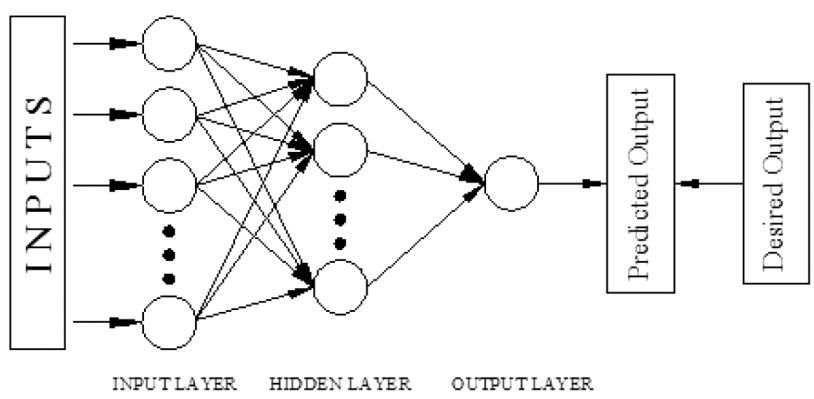

Figure 2: The structure of the ANN Slika 2: Struktura ANN multiplied by the input value received from the preceding layer neuron, $x_{j}$, for each connection path: ${ }^{13}$

$$
x_{i}=w_{i 0}+\sum_{j=1}^{N} w_{i j} \times x_{j}
$$

where $N$ is the number of inputs, $w_{i 0}$ is the bias of the neuron.

The output from neuron $i, V_{i}$, is given by:

$$
V_{i}=f\left(x_{j}\right)
$$

where $f$ is the activation function.

During training, $Q$ sets of input and output data are given to the neural network. An iterative algorithm adjusts the weights so that the outputs $\left(y_{\mathrm{k}}\right)$ according to the input patterns will be as close as possible to their respective desired output patterns $\left(d_{\mathrm{k}}\right)$. Considering a neural network with $K$, which is the total number of outputs, the Mean Squared Error (MSE) function is to be minimized:

$$
M S E=\frac{1}{Q \cdot K} \cdot \sum_{q=1}^{Q} \sum_{k=1}^{K}\left[d_{k}(q)-y_{k}(q)\right]^{2}
$$

The backpropagation algorithm is the most widely used to minimize $M S E$ by adjusting the weights of the connection links. The equation for calculating the updated weights and bias is:

$$
w_{i j}^{t+1}=w_{i j}^{t}+\Delta w_{i j}^{t+1}
$$

Where $\Delta w_{i j}^{t+1}$ is the $( \pm)$ incremental change in the weight. The weight change is determined by an optimization method. ${ }^{13}$

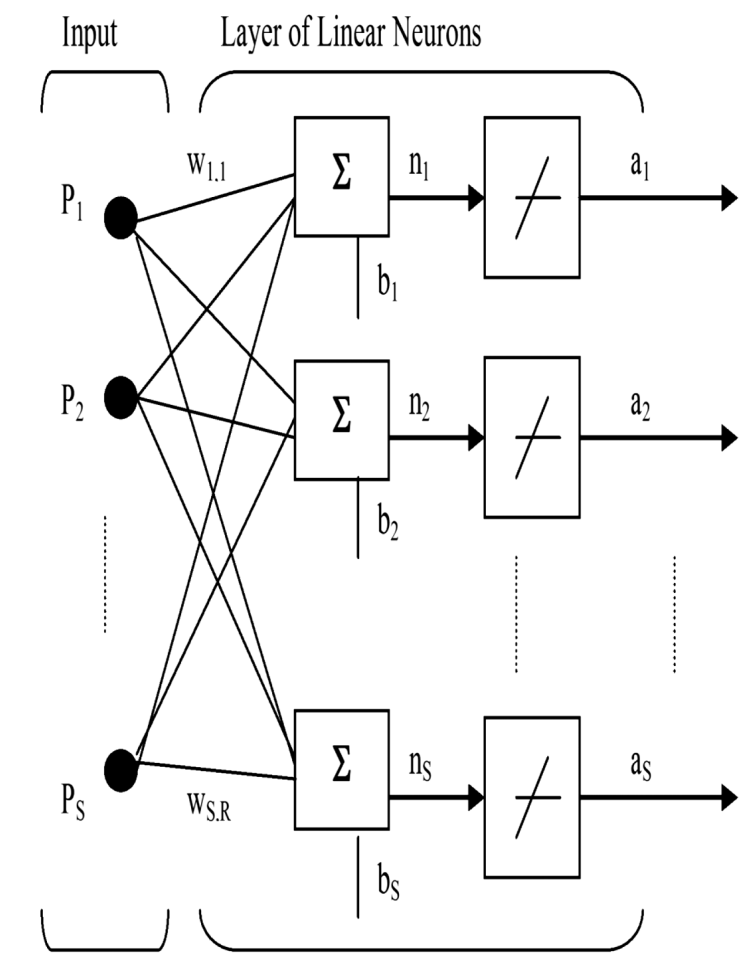

Figure 3: The linear network structure ${ }^{14}$

Slika 3: Struktura linearne mreže $\mathrm{e}^{14}$ 


\section{ANN MODEL}

Linear and Nonlinear Neural Network models were developed for the raw-material blending process in cement manufacture. The inputs of both the models are low grade and iron ore, and the outputs are $\mathrm{Fe}_{2} \mathrm{O}_{3}$ and Lime Modulus.

\subsection{Linear ANN}

The linear network (ADALINE network) shown in Figure 3 has one layer of $S$ neurons connected to $R$ inputs through a matrix of weights $W .^{14}$

The linear network has the same basic structure as the perceptron network. The only difference is that the linear neuron uses a linear transfer function. This transfer function is shown in Figure 4. The linear transfer function calculates the neuron's output by simply returning the value passed to it. This neuron can be trained to learn an affine function of its inputs, or to find a linear approximation to a nonlinear function. A linear network cannot, of course, be made to perform a nonlinear computation. ${ }^{14}$

A nonlinear relationships between the inputs and the targets cannot be represented exactly by a linear network. Under se circumstances, backpropagation might be a good alternative.

\subsection{Nonlinear ANN}

The nonlinear network is shown in Figure 5. ${ }^{14}$ In this study a feed-forward backpropagation network was designed. A log-sigmoid transfer function was used in a hidden layer and the output layer. Because, generally, a natural incident resembles the structure of a log-sigmoid function, using this function has given better results. A log-sigmoid transfer function is shown in Figure 6. ${ }^{14}$ The inputs to the system determine the neuron number in the input layer of the network and its outputs determine the neuron number in output layer of network. Eight neurons were used in the hidden layer of the model.

A neural network requires that the range of the both input and output values should be between 0.1 and 0.9

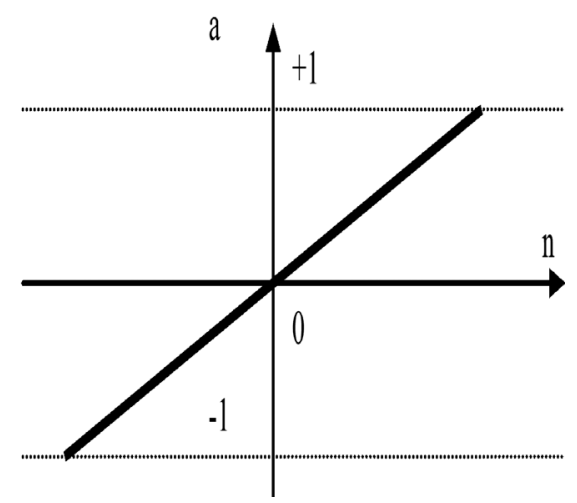

Figure 4: Linear transfer function ${ }^{14}$

Slika 4: Linearna prenosna funkcija 14

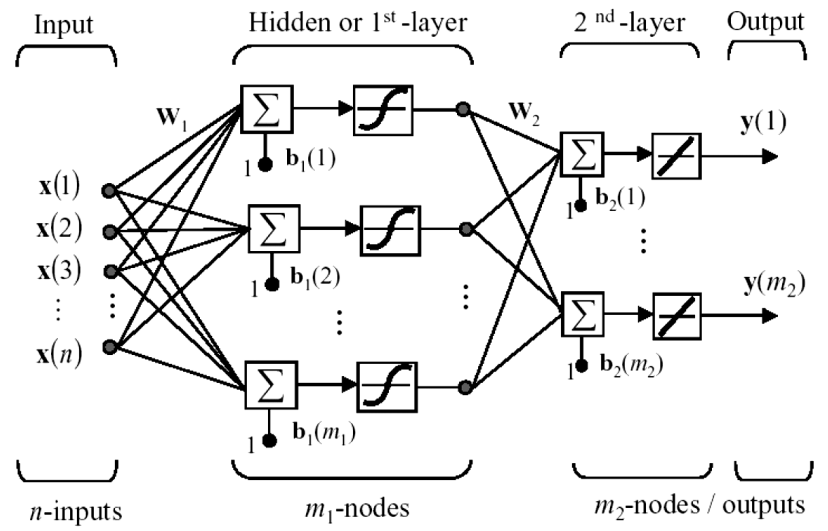

Figure 5: The nonlinear network structure ${ }^{14}$

Slika 5: Struktura nelinearne mreže ${ }^{14}$

due to the restriction of the sigmoid function, consequently, the data must be unified.

Normalize data $=\frac{\text { Actual value }- \text { Minimum value }}{\text { Maximum value }- \text { Minimum value }} \times$
$\times($ High - Low $)+$ Low

is a widely employed method in unification. ${ }^{15}$

In this study, the backpropagation network training function updates the weight and bias values according to the Levenberg-Marquardt optimization. The performance index was determined by the mean squared error. The Levenberg-Marquardt algorithm is very well suited to neural network training where the performance index is the mean squared error.

\section{RESULTS}

The input-output data set for the neural network training and testing were obtained from experiments in the Nuh Cement Factory. A data set of 455 samples was used to train the neural network model. A data set of 200 samples was utilized to test the network model.

The input and output data were used by the network in the training stage and the network learned the process. After the network was trained, the $\mathrm{Fe}_{2} \mathrm{O}_{3}$ and Lime Modulus for different combinations of low grade and
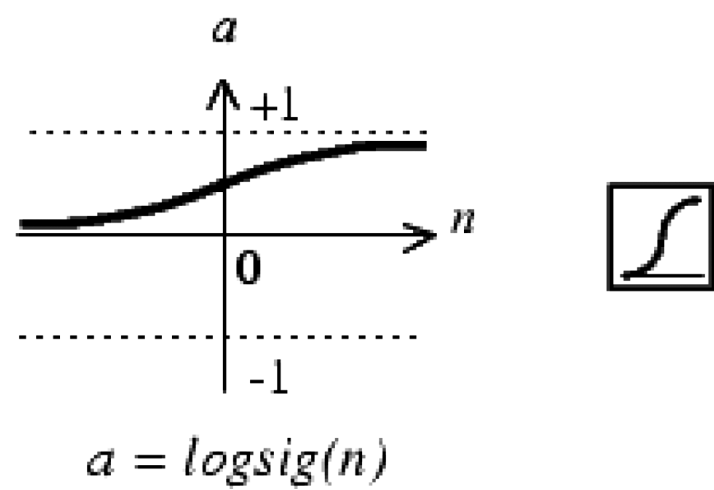

Figure 6: Log-Sigmoid transfer function ${ }^{14}$ Slika 6: Log-Sigmoid prenosna funkcija ${ }^{14}$ 


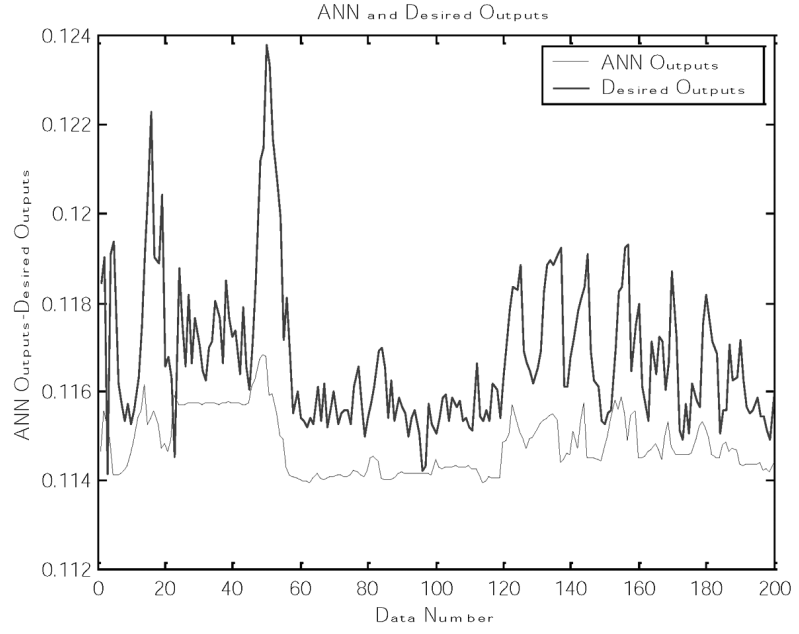

Figure 7: Comparison of the linear neural network prediction with the experimental data (for $\mathrm{Fe}_{2} \mathrm{O}_{3}$ )

Slika 7: Primerjava napovedi linearne nevronske mreže z eksperimentalnimi podatki $\left(\mathrm{za} \mathrm{Fe}_{2} \mathrm{O}_{3}\right)$

iron ore from the test data set were predicted. Figures 7 and $\mathbf{8}$ show a comparison of the linear neural network prediction with the experimental data. The comparison of the nonlinear neural network prediction with the experimental data is shown in Figures 9 and $\mathbf{1 0 .}$

During training, the mean squared errors were recomputed using next updated weights and the performance graphic was obtained for the nonlinear network in Figure 11. The goal in the figures is the target value of the MSE and the performance is the MSE value obtained from the ANN training result. As shown in Figure 11, the error decreases rapidly in the next iterations.

$\mathrm{The} \mathrm{Fe}_{2} \mathrm{O}_{3}$ prediction of the models indicated that the maximum error between the linear neural network results and desired outputs is about $7.5 \times 10^{-3}$ and maximum error between nonlinear neural network results and the desired outputs is about $4 \times 10^{-3}$. For the Lime Modulus

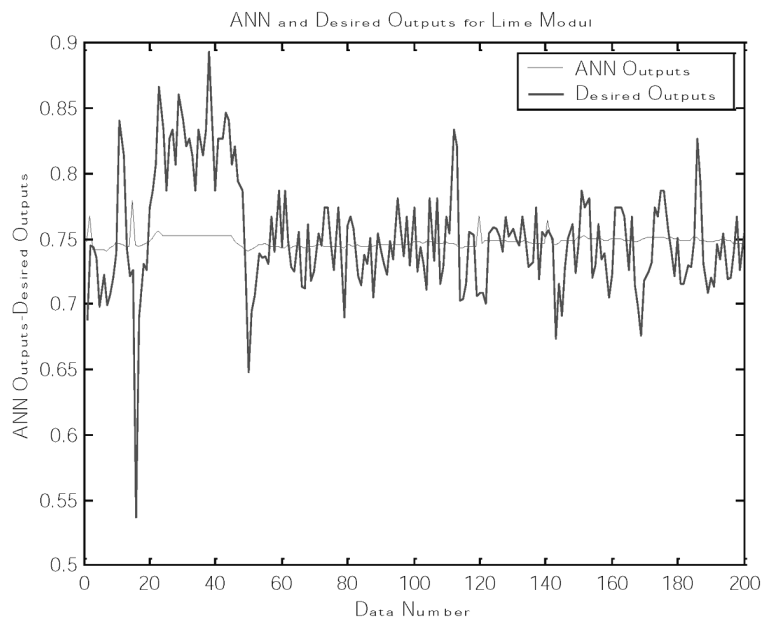

Figure 8: Comparison of the linear neural network prediction with experimental data (for Lime Modulus)

Slika 8: Primerjava napovedi linearne nevronske mreže z eksperimentalnimi podatki (za module $\mathrm{z}$ apnom)

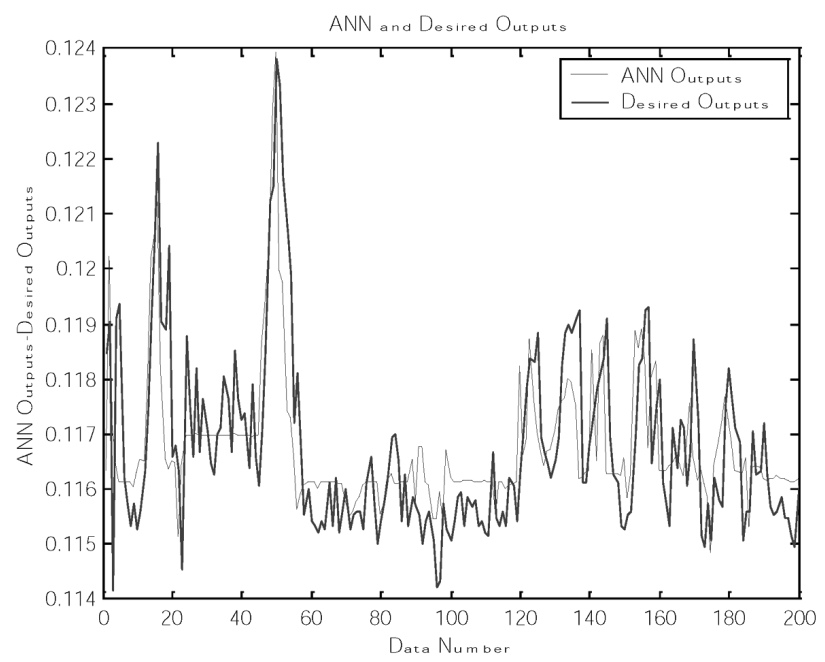

Figure 9: Comparison of the nonlinear neural network prediction with the experimental data (for $\mathrm{Fe}_{2} \mathrm{O}_{3}$ )

Slika 9: Primerjava napovedi z nelinearno nevronsko mrežo z eksperimentalnimi podatki $\left(\mathrm{za} \mathrm{Fe}_{2} \mathrm{O}_{3}\right)$

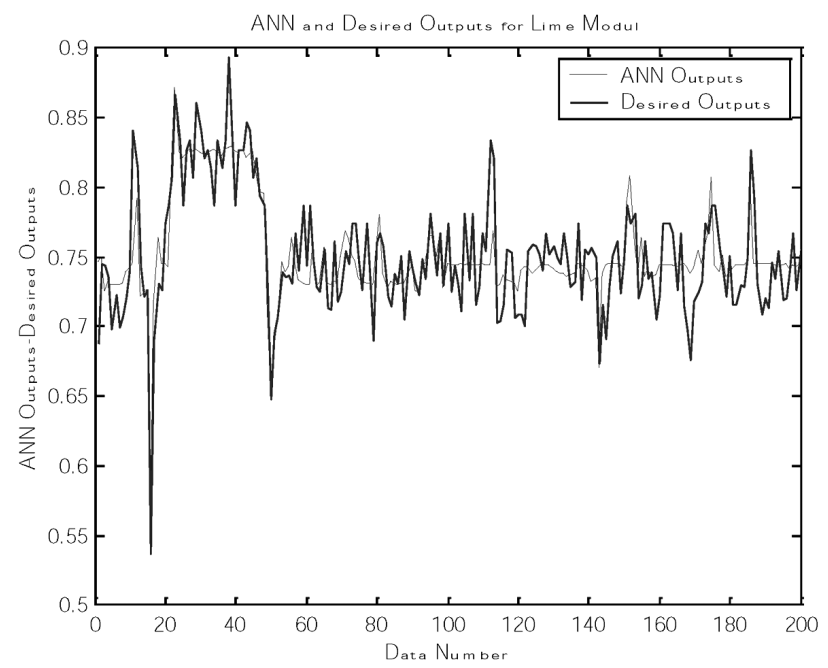

Figure 10: Comparison of the nonlinear neural network prediction with the experimental data (for Lime Modulus)

Slika 10: Primerjava napovedi nelinearne nevronske mreže z eksperimentalnimi podatki (za module $\mathrm{z}$ apnom)

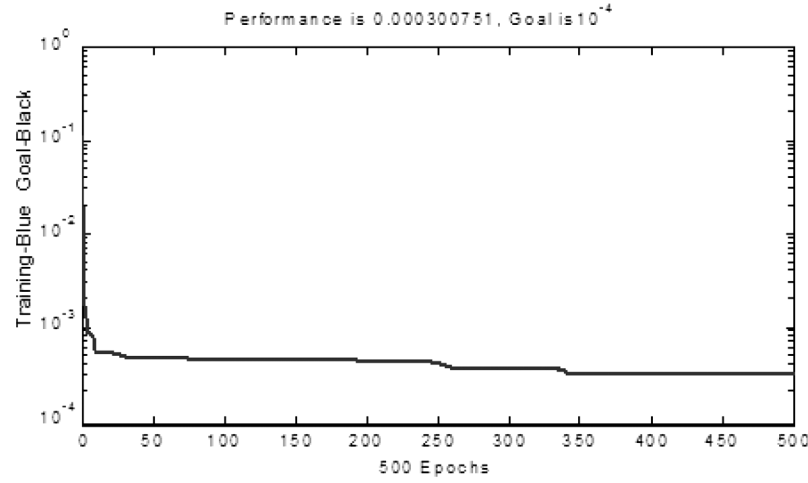

Figure 11: Performance of the nonlinear neural network Slika 11: Uspešnost nelinearne nevronske mreže 
output of the models, the maximum error of the linear neural network is about -0.21 and the maximum error of the nonlinear neural network is about 0.095. Furthermore, the training performance $(M S E)$ of the nonlinear neural network reached $3.00751 \times 10^{-4}$ at 500 epochs. The meaning of the MSE being very small is that the desired outputs and the ANN's outputs for the training set have become very close to each other.

\section{CONCLUSION}

In this study the raw-material blending process in a cement factory was examined and two different mathematical models were developed using linear and nonlinear neural networks. In this modeling the experimental data were used from a controlled process under varying operating conditions in the Nuh Cement Factory in Turkey. Good parametric multivariable models having the minimum number of parameters were obtained. The inputs are the feed ratios of the raw materials (low grade and iron ore) and the outputs are iron oxide and/or the lime module values of the raw meal.

The developed linear and nonlinear neural network predictions were compared with the experimental results. The network test showed that the nonlinear neural network has a higher predictive accuracy and convergence for the raw-material blending process. The linearmodel-based prediction shows a greater deviation than the nonlinear model. The mathematical model that is established by the nonlinear neural networkis a suitable model for the blending process of cement raw material.

Finally, this multi-input, multi-output model has made possible the control of the iron oxide and the lime module together, instead of using parallel-working single-loop controllers. In this case only the lime module or the iron oxide could have been controlled, depending on the choice in the Nuh Cement Factory with the available control package, designed models give the opportunity for these outputs to be controlled together by using a two-input, two-output process model. Furthermore, stable operating conditions can predict the process with these models.

\section{REFERENCES}

${ }^{1}$ K. T. Westerlund, H. Toivenon, K. E. Nyman, Stochastic modelling and self-tuning control of a continuous cement raw material mixing system, Proceeding of the 18th IEEE Conference on Decision and Control, Fort Lauderdale, Florida 1979, 610-615, doi:10.1109/ CDC.1979.270255

${ }^{2}$ M. Hubbard, T. Dasilva, Estimation of feedstream concentrations in cement raw material blending, Automatica, 18 (1982) 5, 595-606, doi:10.1016/0005-1098(82)90011-5

${ }^{3}$ L. Keviczky, J. Hetthéssy, M. Hilger, J. Kolostori, Self-Tuning adaptive control of cement raw material blending, Automatica, 14 (1978) 6, 525-532, doi:10.1016/0005-1098(78)90042-0

${ }^{4}$ P. Lin, Y. S. Yun, J. P. Barbier, P. Prevot, Intelligent tuning and adaptive control for cement raw meal blending process, Proceedings of the IFAC Intelligent Tuning and Adaptive Control, Singapore 1991, 301-306, doi:10.1016/B978-0-08-040935-1.50053-3

${ }^{5}$ A. K. Swain, Material mix control in cement plant automation, IEEE Transactions on Automatic Control, 15 (1995) 4, 23-27, doi: $10.1109 / 37.408464$

${ }^{6}$ C. Ozsoy, A. Kural, M. Cetinkaya, S. Ertug, Constrained MIMO self-tuning composition control in cement industry, 7th International Conference on Emerging Technologies and Factory Automation 20-22, Barcelona 1999, 1021-1027, doi:10.1109/ETFA.1999.813103

${ }^{7}$ A. Kural, C. Ozsoy, Identification and control of the raw material blending process in cement industry, Int. J. Adapt. Control Signal Process, 18 (2004) 5, 427-442, doi:10.1002/acs.805

${ }^{8}$ K. Kizilaslan, S. Ertuğrul, A. Kural, C. Ozsoy, A comparative study on modeling of a raw material blending process in cement industry using conventional and intelligent techniques, In: IEEE Conference on Control Applications 1, June 23-25 Istanbul 2003, 736-741, doi:10.1109/CCA.2003.1223529

${ }^{9}$ G. Bavdaz, J. Kocijan, Fuzzy controller for cement raw material blending, Transactions of the Institute of Measurement and Control, 29 (2007) 1, 17-34, doi:10.1177/0142331207070362

${ }^{10}$ C. Banyasz, L. Keviczky, I. Vajk, A novel adaptive control system for raw material blending. IEEE Control Systems Magazine, 23 (2003) 1, 87-96, doi:10.1109/MCS.2003.1172832

${ }^{11}$ X. Wu, M. Yuan, H. Yu, Soft-sensor modeling of cement raw material blending process based on fuzzy neural networks with particle swarm optimization, Proceedings of the International Conference on Computational Intelligence and Natural Computing, 2009, 158-161, doi:10.1109/CINC.2009.186

${ }^{12}$ X. Li, H. Yu, M. Yuan, Modeling and Optimization of Cement Raw Materials Blending Process, Mathematical Problems in Engineering, (2012), 1-30, doi:10.1155/2012/392197

${ }^{13}$ R. Kazan, M. Firat, A. E. Tiryaki, Prediction of springback in wipebending process of sheet metal using neural network, Materials and Design, 30 (2009) 2, 418-423, doi:10.1016/j.matdes.2008.05.033

${ }^{14}$ M. H. Beale, M. T. Hagan, H. B. Demuth, Neural network design, 2008

${ }^{15}$ I. A. Basheer, M. Hajmeer, Artificial Neural Networks: Fundamentals, Computing, Design, and Application, Journal of Microbiological Methods, 43 (2000) 1, 3-31, doi:10.1016/S0167-7012(00) 00201-3 